\title{
Observations on the vegetation and vascular plants of Hopen
}

\section{ERIK SKYE}

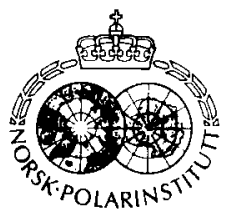

\begin{abstract}
Skye, E. 1986: Observations on the vegetation and vascular plants of Hopen. Polar Research 4 n.s. 69-78.

The vascular plant flora of the small arctic island of Hopen, located in the Barents Sea, was inventoried during a visit in the summer of 1982. Eighteen vascular plant species were observed and mapped, and the vegetation described.
\end{abstract}

Erik Skye, Vaxtbiologiska institutionen, P.O. Box 559, S-751 22 Uppsala, Sweden.

Hopen is a small island situated in the Barents Sea, about $210 \mathrm{~km}$ east of the southern point of Spitsbergen. It is $34 \mathrm{~km}$ long, with an area of $47 \mathrm{~km}^{2}$. During normal years, Hopen is surrounded by ice for ten months of the year. July and August are the warmest months, with an average temperature of $+2^{\circ} \mathrm{C}$. The average annual precipitation is $383.8 \mathrm{~mm}$, and September has the greatest monthly precipitation. The air humidity is high, as is the frequency of fog and cloud cover.

Botanical inventories of Hopen have been made on four different occasions: by A. E. Eaton in 1873 , E. Koefoed in 1924, 1929, and 1930, H. J. Schweitzer in 1970 , and by myself in 1982 .

In the present investigation the northernmost part of the island was excluded. This was because the vegetation there has been greatly influenced as a result of oil prospecting at the beginning of the seventies. The different plant localities are described. Cerastium regelii, Cochlearia officinalis var. groenlandica, Saxifraga oppositifolia, $S$. cernua, S. cespitosa, and, among the grasses, Phippsia algida, are the most commonly occurring species on Hopen. A total of 18 species are mapped. The rarest species are Oxyria digyna and Alopecurus alpinus. All of the vascular plant species observed on Hopen occur commonly in Svalbard.

\section{General description of Hopen}

\section{Location}

The island of Hopen is part of the Svalbard archipelago and is situated in the Barents Sea, approxi- mately $210 \mathrm{~km}$ east of the southern point of Spitsbergen. The shortest distance to the closest island, Edgeøya, is about $95 \mathrm{~km}$ (Fig. 1). Kapp Thor, the southernmost point of Hopen, is located at $76^{\circ} 28^{\prime} \mathrm{N}, 24^{\circ} 50^{\prime} \mathrm{E}$.

\section{Topography}

Hopen is $34 \mathrm{~km}$ long, with an area of $47 \mathrm{~km}^{2}$. It can be considered a horst landscape leaning NNE, and cut by four distinct 'skards' (passes) lying somewhat over $60 \mathrm{~m}$. The horst slopes somewhat ESE, the west side consistently higher and steeper than the east.

Hopen consists of stratified rock, which influences the topography. The mountains are all rather similarly formed, with extensive top plateaux lacking prominent peaks. Plateaux, scree slopes, and steep cliffs are characteristic of Hopen. Weathering soils are extensive. Neither till nor erratics have been observed.

The sea around the island is quite shallow. In some places a motorboat must be driven some kilometres away from the shore in order to travel safely.

\section{Geology}

Werenskiold (in Iversen 1926:25 f.) notes that Hopen consists of rocks belonging to the Neocomian division of the Cretaceous, as do adjacent parts of Spitsbergen. Traces of plant remnants and shells are found in the fossil-bearing strata. The in situ occurrence of coal has not been observed but has been seen as erratics. 


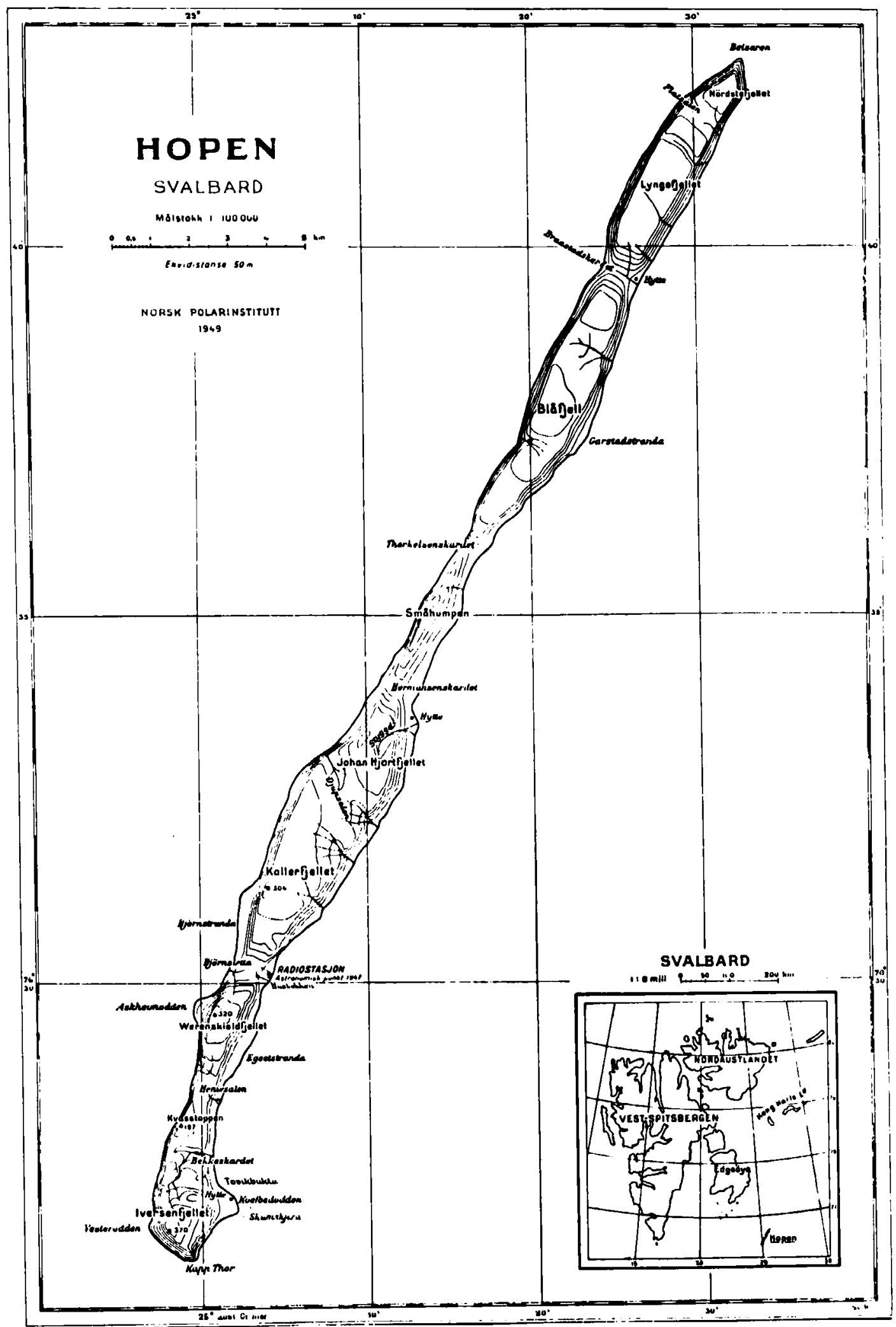

Fig. 1. Map of Hopen island. 


\section{Climate}

Hopen's meteorological station is located in Husdalen at a latitude of $70^{\circ} 30^{\prime} \mathrm{N}, 25^{\circ} 04^{\prime} \mathrm{E}$. Weather observations were started in November 1944 by German occupation soldiers and have been made since 1945 under the auspices of Norway. The present station, lying $7 \mathrm{~m}$ a.s.l. and about $20 \mathrm{~m}$ from the sea, has a staff of four.

Hopen is normally surrounded by ice for 10 months of the year (Steffensen 1969). The cold ocean current that comes down from the north along the eastern coast of Spitsbergen, is also of significance to the climate.

Wind patterns. - The low air pressure during the winter largely produces northeast winds on Hopen. Among other things, this leads to there being significantly more permanent snowbanks on the west side of the island than on the east side. Indeed, the northeastern winds dominate during the summer too, but the frequency of winds from the west is fairly great (Steffensen, op. cit.) (Fig. 2).

Air temperature. - The air temperature is evident from the diagram (Fig. 3). The frequent cloudiness and fog prevent the air temperature from reaching high values. The ice conditions influence the temperature giving the climate a continental

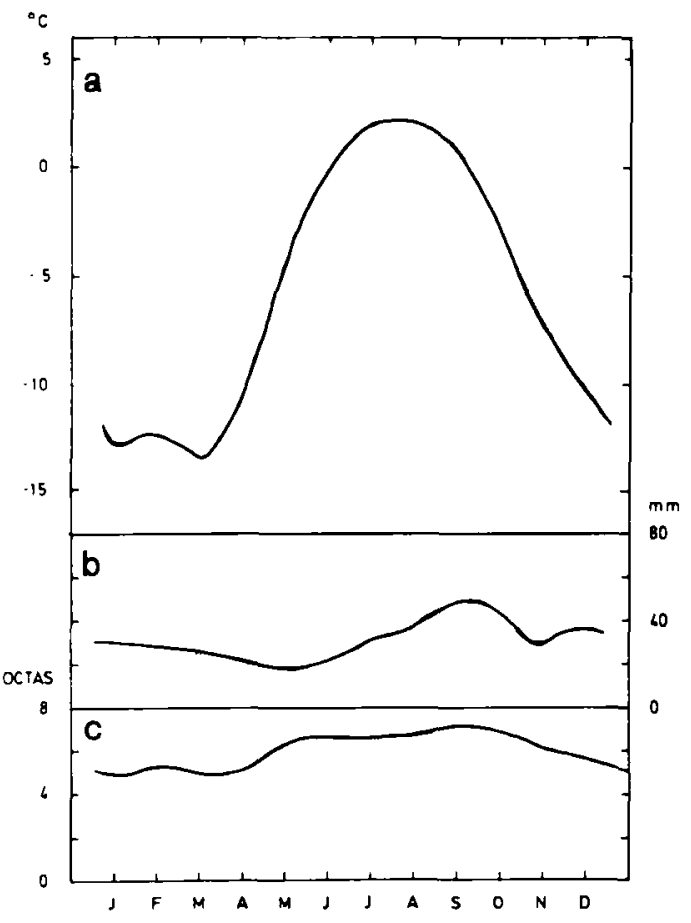

Fig. 3. Temperature, precipitation, cloudiness on Hopen.

character when the sea around Hopen is covered with ice. The climate is more maritime when the sea is open.

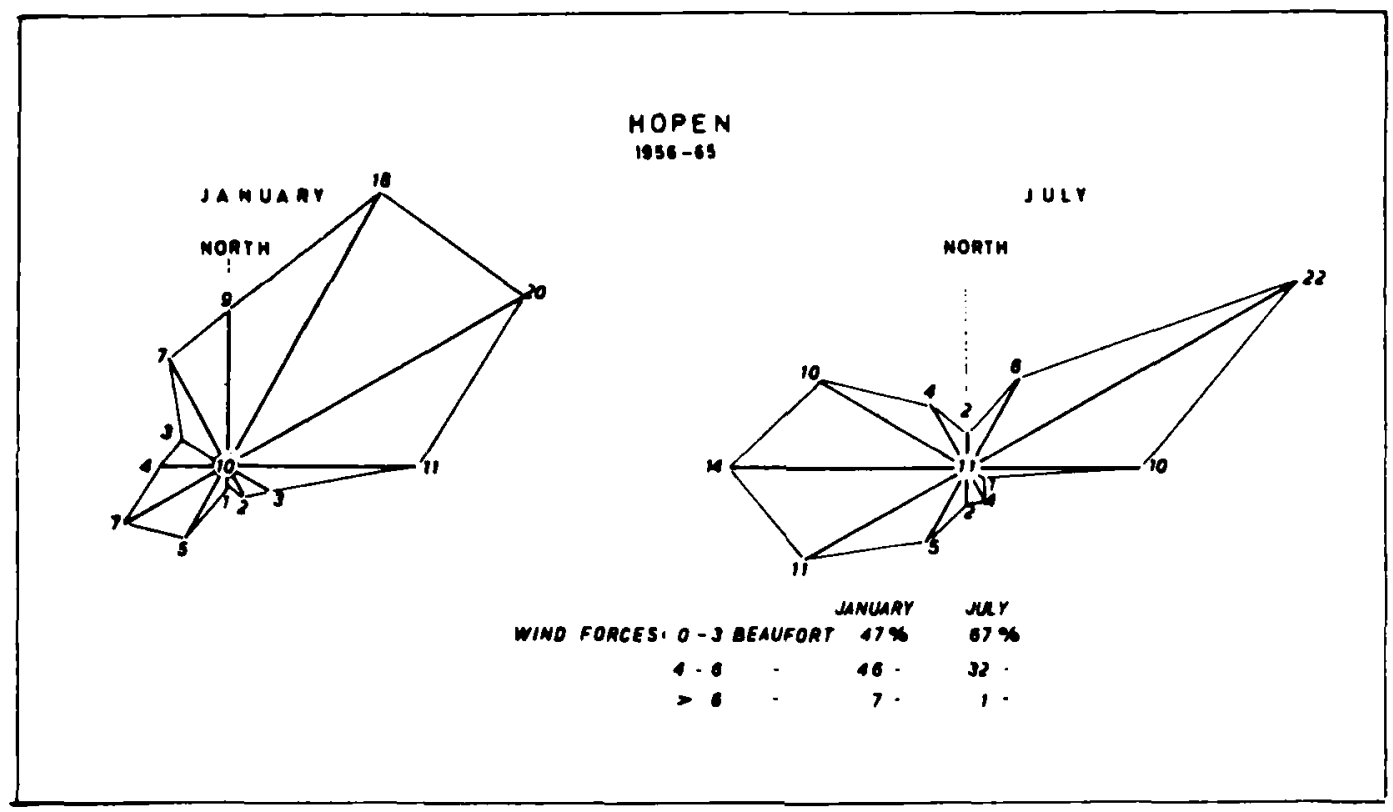

Fig. 2. Wind rose (after Steffensen 1969). 
Humidity. - The average monthly humidity value is between $80 \%$ and $95 \%$. The maximum is reached during the summer months (Steffensen, op. cit.), thus compensating the vegetation for the low precipitation.

Precipitation. - The distribution of precipitation during the year is evident from the diagram (Fig. 3 ). The average annual precipitation is as low as $383.8 \mathrm{~mm}$, and usually falls in the form of light snow, rain, or drizzle. There are often days with between 0.1 and $1.0 \mathrm{~mm}$ precipitation. Rain can occur even in the winter, as can snow during the summer (Steffensen, op. cit.). Cloudiness is frequent and there are few cloudless days. The summer months are cloudier than the winter months (Fig. 3). The average value for cloudiness from June through October is $85-90 \%$.

Fog and low-lying clouds. - The frequency of fog during the summer is quite high, but low during the winter (Steffensen, op. cit.). Fog can appear suddenly and disappear equally fast.

The weather conditions which favour the occurrence of fog, also favour the formation of stratus clouds. The frequency of cloud cover and of fog therefore show the same pattern.

Length of the growth period. - According to the available observations, the length of the growth period scarcely exceeds 90 days, if it is defined as the number of days and nights with an average temperature above $\pm 0^{\circ} \mathrm{C}$. Night-time temperatures below $\pm 0^{\circ} \mathrm{C}$ can occur during the entire growth period.

\section{Vegetation cover}

Topographically, Hopen can be said to consist of five different elements: mountain plateaux and ravines, areas of scree, bird cliffs, beach ridges, and beaches composed solely of inorganic material.

The plateaux are fairly flat and tilt weakly to the northeast. For the most part the substratum is fine-grained weathering soil that is very stony in places, and holds a great deal of water during much of the vegetational period. Permafrost is found at a depth of $25-35 \mathrm{~cm}$, but is somewhat deeper at the end of the summer. The ground is supplied with abundant water from large snowbanks and from the thawing of the soil that persists even at the turn of the months July and August.
Because of the topography the drainage is fairly slow. Continuous carpets of moss can occur here and there, especially where the substrate is somewhat stony. In the moss there are scattered vascular plants, for example Saxifraga oppositifolia, $S$. cernua and $S$. cespitosa as well as occasional grass, chiefly Phippsia algida. Most prominent, however, is Cerastium regelii, which forms dense, green cushions of about the size of tennis balls. This is the species that gives character to the sparse vegetation. Cerastium regelii also occurs on ground not covered by moss, although more sporadically, often together with Saxifraga cernua and Phippsia algida, among others. This type of vegetation is found on all the mountain plateaux on Hopen. Additional single species may occur.

The situation is generally similar in the 'skards' between the mountains. Under certain conditions the exposure is somewhat less. Drier areas characterized by solifluction occur between waterlogged areas. As the surface of the solifluction lobes is relatively stable and dry, the vegetation is denser and has more species.

Heaths covered by lichens do not occur on Hopen. The lichen flora is poor. Cetraria nivalis, C. delisei, $C$. islandica occur sporadically, and Cladonia uncialis, and $C l$. rangiferina have been observed.

The substrate in the scree area consists of weathering debris with an admixture of marine deposits. In stable areas rows of more or less continuous moss cover are formed, containing most of the vascular plants of Hopen. In the areas of scree exposed to the east, Papaver dahlianum, Cerastium arcticum, C. regelii, Saxifraga oppositifolia, $S$. cernua, and $S$. cespitosa, as well as the grasses, especially Phippsia algida, can occur fairly profusely. Scree slopes exposed to the west are usually covered by snow.

The beach ridges are usually covered by a more or less continuous moss vegetation. However, sections without vegetation occur and become larger the farther north one comes on Hopen. The substrate is relatively stable. Dry sections extend between fairly deeply cut streams that flood large areas during the melting of the snow and wash the vegetation away.

The largest beach ridges are situated on the east side of the island, namely Koefoedodden, Husdalen near the radio station, the eastern end of Hermansenskardet, and along the eastern side of Småhumpen north towards Thorkelsenskardet. On the west side it is mainly Bjørnsletta and 
the western end of Hermansenskardet that are noticeable.

The beach ridges are enriched by organic matter that has been drifting ashore for thousands of years, as well as by the remains of dead animals, primarily whales, walrus, polar bears and seals, that have either stranded or been killed on the beach. It is largely when associated with such remnants that the vegetation becomes denser and more or less continuous. The abundant occurrence of goose droppings was observed on Bjørnstranda. Phippsia algida and Cochlearia officinalis were noted among the plants. In places, numerous finds of Phippsia algida almost form a carpet over fairly large areas around the buildings in Husdalen.

The shore completely lacks vegetation. Because of the waves and even more, the activity of the ice, the rather coarse material is in constant motion and prevents the establishment of vegetation.

\section{The botanical investigations on Hopen}

It has been difficult to find information about botanical visits to Hopen. The island is too far away and much too small to be a tempting destination.

\section{Eaton's visit in 1873}

In the summer of 1873 , during the third cruise to the Greenland Sea in the Order of the Polar Star, under the command of Captain B. Leight Smith, Alfred Edvin Eaton collected both plants and animals in the Svalbard area. Phanerograms and higher cryptogams were worked out by $\mathrm{Mr}$. Le Marchant Moore. The expedition found a total of twelve different vascular plants on Hopen (Eaton 1876). How long the expedition stayed on the island, and which parts of it they visited are unknown. The time of the visit is not mentioned.

\section{Koefoed's collection in 1924}

At the turn of the months July-August, 1924, Hopen was visited by the $\mathrm{M} / \mathrm{C}$ Torvik under the command of Captain Thor Iversen. On this occasion zoologist Einar Koefoed made a collection of vascular plants (among other things), which were later identified by Johannes Lid (in
Iversen 1926). The collection contained sixteen different species, eight of which had not been found previously.

Iversen and Koefoed also visited Hopen in 1929 , this time in the middle of September. It was cold, and only a few plants were noted. No new discoveries were made. In September 1930 Hopen was visited again; seven different vascular plants from the south slope of Lyngefjell down towards Braastadskardet were later noted from this visit. No new species were mentioned (Iversen 1941).

\section{Schweitzer's visit in 1970}

During an expedition to Spitsbergen (Van Mijenfjorden) in 1970, the expedition leader, Dr. Schweitzer, also visited Hopen. He noted a total of eighteen vascular plants on the southern part of the island, up to Husdalen (Engelskjön et al 1972). Schweitzer found five new species.

\section{The present investigation}

I visited Hopen in the summer of 1982, accompanied by two physical geographers, Lars Brydsten and Rolf Zale. During the few weeks from July 24 to August 10, I collected and observed the occurrence of vascular plants from a large part of the island. Only the northernmost region, north of Thorkelsenskardet, was omitted, as it had been greatly influenced by test drilling for oil in the 1970s.

\section{Remarks on the individual species}

Oxyria digyna (L.) Hill.

According to Rønning (1979) this species is distributed all over Svalbard and is very common. It belongs to the newly discovered species on Hopen and only a few specimens occur there (Fig. 4a). One of them formed a pronounced tussock with large leaves, but with short stalks; the others were very small. In $1965 \mathrm{H}$. Österholm (pers. commun.) observed the species on Hopen. It is circumpolar, arctic-alpine (Hultén 1971), and spreads by seed.

\section{Cerastium regelii Ostf.}

Rønning (1979) states that this species is distributed all over Svalbard and that it is very com- 

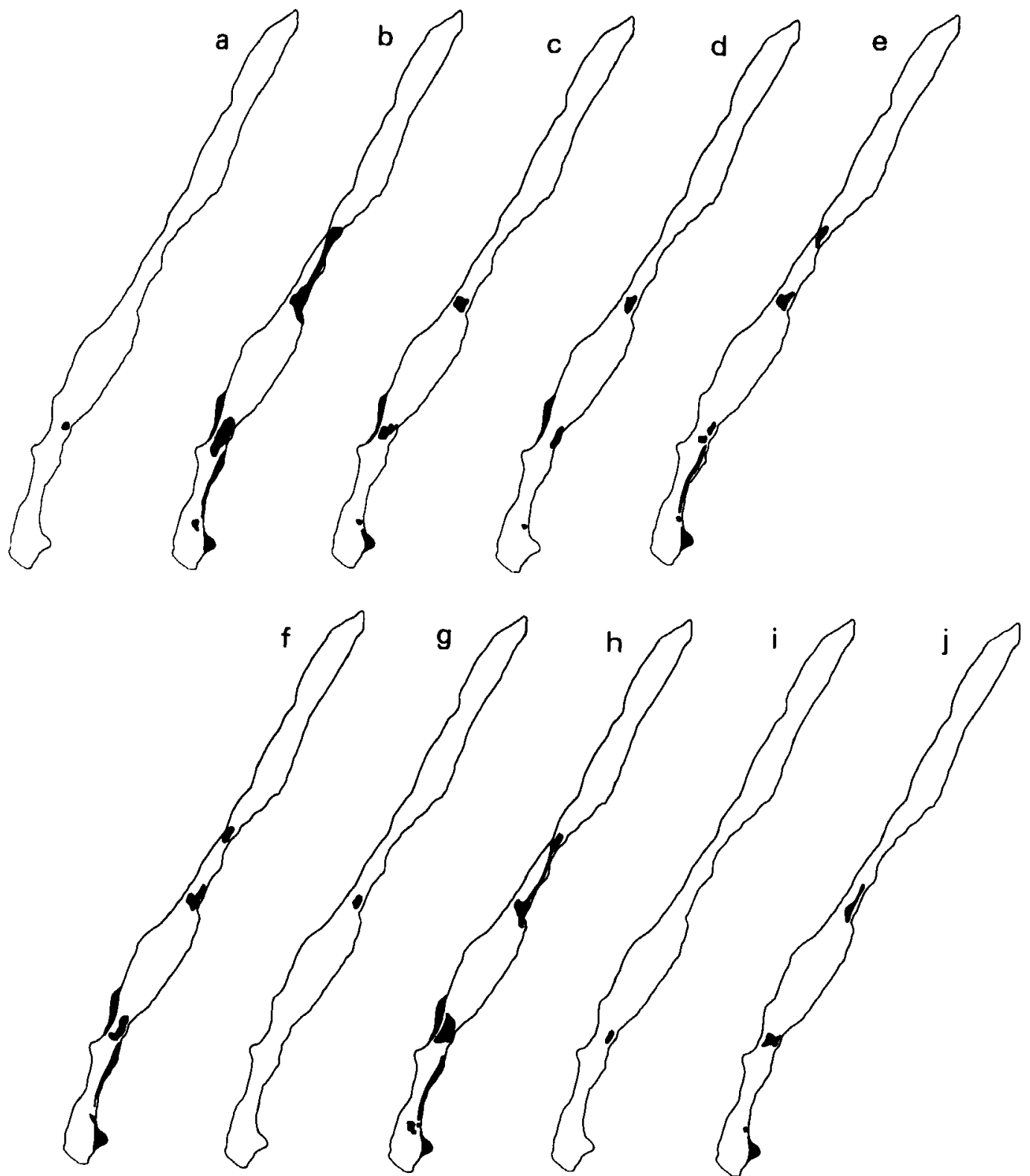

Fig. 4. Distribution map. a. Oxyria dignya (L) Hill.; b. Cerastium regelii Ostf.; c. Cerastium arcticum Lgc.; d. Ranunculus sulphurus Sol.; e. Papaver dalianum Nordh.; f. Cochlearea officinalis L.; g. Draba adamsii Ledeb.; h. Saxifraga oppositifolia L.; i. Saxifraga nivalis L.; j. Saxifraga tenuis (Wahlenb.) H. Sm.

mon even on higher elevations. It is possibly the most common species on Hopen (Fig. 4b) but was not noted by Eaton in 1873. It is one of the few species that grows on the mountain plateaux, and is commonly sterile and spreads vegetatively. $C$. regelii is considered by Hultén (1958) to be amphiatlantic and high arctic, whereas Polunin (1959) considers it to be circumpolar-arctic with gaps on both sides of the Bering Sound.

Cerastium arcticum Lge.

This species is distributed all over Svalbard, both in the lowlands and in the mountains, according 
to Rønning (1979). It is fairly common on Hopen, although it occurs rather sporadically and as lowflying tussocks (Fig. 4c). It blooms meagerly at the beginning of August. Hultén (1958) considers the species to be amphi-atlantic. Polunin (1959), who does not separate $C$. arcticum and $C$. alpinum, considers it circumpolar.

\section{Ranunculus sulphureus Soland.}

This species is reported by Rønning (1979) to be distributed all over Svalbard and to be fairly common. On Hopen it is relatively rare and is quite low where it does grow. Distribution is shown in Fig. 4d. The flowers lack the black hairs between the fruits, which normally characterize the species. In this case the specimens found were more like $R$. nivalis, but the leaves are typical of $R$. sulphureus. Infrequent flowering was observed at the beginning of August. Polunin (1959) states that $R$. sulphureus hybridizes with $R$. nivalis. Hultén (1971) discusses the differences between the two species and states that consideration of the leaf characteristics alone is not completely reliable. $R$. sulphureus has been mentioned in all the inventories from Hopen, but $R$, nivalis has never been mentioned.

\section{Papaver dahlianum Nordh}

Rønning (1979) reports that this species is distributed all over Svalbard. It is fairly common on the east side of Hopen (Fig. 4e) and blooms fairly profusely at the beginning of August. The petals are pale yellow. Hultén (1958) claims that the total distribution is amphi-atlantic with the area of greatest concentration on both sides of Framsundet. In the inventory from $1873, P$. nudicaule L. was mentioned (Eaton 1876). Lid (1926) noted $P$. radicatum Rottb. Both must be considered to be $P$. dahlianum.

\section{Cochlearia officinalis L.}

According to Rønning (1979) three varieties occur on Svalbard, but the genus is highly in need of revision. Most of the observed Hopen material seems to agree with $C$. officinalis var. groenlandica (Fig. 4f), which is also considered by Rønning (op. cit.) to be the most common taxon in Svalbard. However, it was not noted by Eaton (1876). In places it blooms profusely at the end of July and beginning of August. It is circumpolar according to Hultén (1971), who does not distinguish the variety groenlandica but evidently considers it a dwarf form of the subspecies arctica (Schlecht.) Hult.

\section{Draba adamsii Ledeb.}

According to Rønning (1979) this species is common in certain places but its total distribution in Svalbard is not well known. On Hopen a few small tussocks occur in Hermansenskardet and it is one of the rarest species on the island (Fig. $4 \mathrm{~g}$ ). It is not previously reported. Meager blooming at the beginning of August. Total distribution not investigated. Rønning distinguishes $D$. adamsii (syn. D. oblongata) from $D$. micropetala.

\section{Saxifraga oppositifolia L.}

This species is widespread and common all over Svalbard, according to Rønning 1979. One of the most common species on Hopen (Fig. 4h). Relatively meager flowering at the beginning of August. Circumpolar, arctic alpine distribution (Hultén 1971). Not mentioned by Eaton (1876).

\section{Saxifraga nivalis $\mathrm{L}$.}

Rønning (1979) states that $S$. nivalis is distributed all over Svalbard. On Hopen it occurs quite infrequently (Fig. 4i). The specimens observed had distinct leaf rosettes and short flower stalks. Blooming started at the beginning of August. The total distribution is circumpolar arctic alpine. See also $S$. tenuis below.

\section{Saxifraga tenuis (Wahlenb.) H. Sm.}

Rønning (1979) reports that this species is distributed all over Svalbard and is common. It is prevalent on Hopen, but never abundant (Fig. $4 \mathrm{j}$ ). It has been observed in all four inventories made on Hopen. The specimens observed had small, fairly dense rosettes and short flower stalks. At the beginning of August there is a meager flowering. The total distribution is circumpolar arctic-montane. Both Hultén (1971) and Polunin (1959) include $S$. tenuis with $S$. nivalis.

\section{Saxifraga cernua L.}

This species is very common over the entire Svalbard area according to Rønning (1979). On 

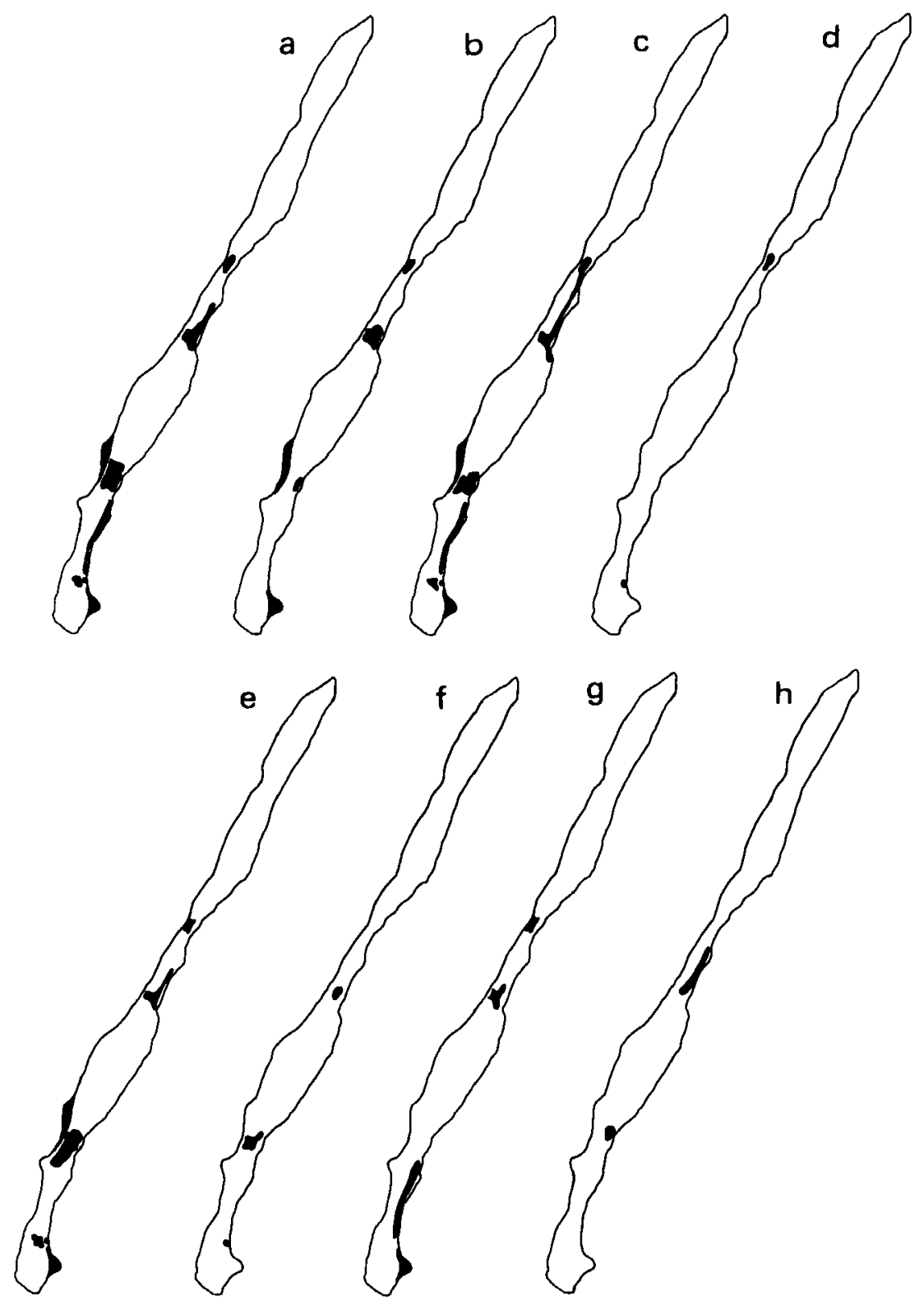

Fig. 5. Distribution map. a. Saxifraga cernua L.; b. Saxifraga rivularis L.; c. Saxifraga cespitosa L.; d. Alopecurus alpinus Sm.; e. Phippsia algida R. Br.; f. Poa alpigena (Fr.) Lindm.; g. Poa arctica R. Br.; h. Poa alpina L.

Hopen it is one of the most common species (Fig. 5a). It occurred in all four reports from Hopen. The specimens observed were all low. The flowering was sparse in the beginning of August. Total distribution is circumpolar arctic alpine (Hultén 1971).
Saxifraga rivularis $\mathrm{L}$.

Rønning reports that the species occurs all over Svalbard and is common. It is fairly common on Hopen (Fig. 5b) in wet carpets of mosses. It is low and sparsely tufted, and blooms at the beginning of August. Eaton (1876) does not men- 
tion this species. $S$. rivularis has a circumpolar distribution (Hultén 1971).

\section{Saxifraga cespitosa $\mathrm{L}$.}

Hultén (1958) considers $S$. cespitosa to be a collective species having many different races and that it has still not been sufficiently studied. $S$. cespitosa $\mathrm{L}$. is very common and widely distributed in Svalbard, according to Rønning (1979). On Hopen it is one of the most common species (Fig. 5c) and has been noted in all four inventories. The specimens I observed all formed tussocks and had many short-stalked flowers at the beginning of August. It is a variable species, with the variety uniflora $\mathrm{R}$. Br. occurring more often on Hopen than the main species. Hultén (1958) states that the species is circumpolar and designates the northern single-blossomed plants ssp. sileneflora (Sternb.) Hult.

\section{Alopecurus alpinus Sm.}

Rønning (1979) reports this species as common all over Svalbard, often occurring in dense clusters. It only occurs at two places on Hopen (Fig. 5d), where it is low $(5-10 \mathrm{~cm})$ and grows sparsely. The species is spread by seed and has been observed during all four inventories. Hultén does not mention A. alpinus in 1958 or in 1962, but Polunin (1959) considers it to be circumpolar.

\section{Phippsia algida (Soland.) R. Br.}

Rønning states that this species is common all over Svalbard. On Hopen it occurs relatively frequently (Fig. 5e), but Eaton (1876) does not mention it. It is one of the few species on the island found up on the mountain plateaux. The total distribution is circumpolar according to Hultén (1962).

Poa alpigena (Fr.) Lindm. incl. var. vivipara (Malmg.) Schol.

This species is distributed all over Svalbard according to Rønning (1979). On Hopen (Fig. 5f) it occurs relatively sparsely in three areas. It often grows in loose tussocks or singly and is then usually sterile, but has subterranean runners. Schweitzer (Engelskjön et al. 1972) was the first to mention it from Hopen. According to Hultén the total distribution is circumpolar.

Poa arctica $\mathrm{R}$. Br. incl. var. vivipara (Malmg.) Schol.

According to Hultén (1958) this is a question of 'an aggregate species including numerous partly apomictic types'. Rønning states that the species is distributed all over Svalbard but not widely. It occurs within several areas of Hopen (Fig. 5g) but is never abundant. Neither Lid nor Schweitzer mention the species from Hopen, but Eaton does. According to Hultén (1958), who does not discriminate var. vivipara, Poa arctica is circumpolar arctic alpine. The subspecies caespitans (Simmons) Nannf., distinguished by Nannfeldt, is amphi-atlantic and is found in Svalbard, but has not been observed with certainty on Hopen.

Poa alpina $\mathrm{L}$. incl. var, vivipara $\mathrm{L}$.

Hultén (1958) refers to Müntzing \& Nygren (1955) and points out that $P$. alpina is 'a very variable agglomerate species composed of generally apomictic biotypes', Rønning (1979) says that var. vivipara is most common and that the species is distributed all over Svalbard. Schweitzer was the first to find it on Hopen. In 1982 the species was rediscovered in two places (Fig. 5h) on the island, and was sparse at both.

\section{Previously reported species not rediscovered}

The turnover is rather high on Hopen. Altogether 26 species have been recorded since 1873 . Of these, the following eight have not been refound:

Draba alpina

Deschampsia alpina

Potentilla hyparctica

Luzula arcuata (= Luzula confusa?)

Puccinellia phryganodes

Ranunculus pygmaeus

Festuca vivipara

Cerastium alpinum

\section{Addendum}

Other species recorded, previously unpublished: Minuartia rubella (O. Hansen, 1930, Herb. O.) Rannunculus hyperboreus (Troms $\emptyset$ Museum Expedition 1983, Herb. TROM). 
Acknowledgements. - Anders Häggblom, Department of Physical Geography, University of Stockholm, Sweden, organized the journey, but unfortunately could not participate himself. Thanks to the Norwegian Polar Research Institute, the Weather Service for North Norway, and the Sysselmann for Svalbard, we received transportation by $\mathrm{M} / \mathrm{S}$ Polarstar to Hopen and got the opportunity to stay there for a couple of weeks. The Norwegian Coast Guard took us home safely on board the $\mathrm{K} / \mathrm{V}$ Nornen under the command of Kapteinløytnant R. Jensen. The crews on both ships made our journeys pleasant. On Hopen we got all the support we needed from the staff of the Radio station. Lars Brydsten and Rolf Zale from the Department of Geography, University of Umeå, Sweden, and I had a very fruitful collaboration. The journey was made possible by grants from the Swedish Natural Science Research Council.

\section{References}

Eaton, A. E. 1876: A list of plants collected in Spitsbergen in the summer of 1873 , with their localities. The Journal of Botany, New Series $V, 41-44$.
Engelskjøn, T., Kramer, K. \& Schweitzer, H-J. 1970: Zur Flora des Van Mijenfjorden-Gebietes (Spitsbergen) und Hopens. Norsk Polarinstitutt Ärbok 1970, 191-198.

Hultén, E. 1958: The amphi-atlantic plants and their phytogeographical connections. K.V.A.:s Handlingar 7, 1 Uppsala.

Hultén, E. 1962: The circumpolar plants. I. vascular cryptogams, conifers, monocotyledons. K.V.A.: $s$ Handlingar 8,5 Uppsala.

Hultén, E. 1971: The circumpolar plants. II. dicotyledons. K.V.A.is Handlingar 13, 1 Uppsala.

Iversen, T. 1926: Hopen (Hope Island), Svalbard. Results of a reconnaissance in the summer 1924. Skrifter om Sualbard og Ishavet 10, Oslo.

Iversen, T. 1941: Ishavsøya Hopen. Fiskeridirektoratets skrifter VI(6) Bergen.

Polunin, N. 1959: Circumpolar Arctic Flora. Oxford.

Rønning, O. I. 1979: Svalbards flora. Norsk Polarinst. Polarhandbok 1. Oslo.

Steffensen, E. 1969: The climate and its recent variations at the Norwegian arctic stations. Meteorologiska Annaler 5, 8. Oslo. 